\title{
低立体規則性ポリプロピレンを用いた スパンボンド不織布の成形性と物性
}

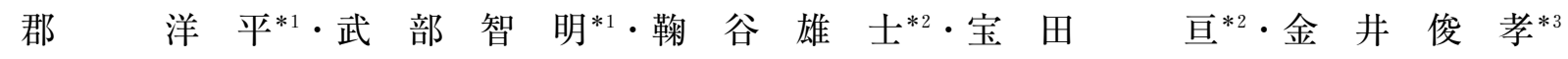

\section{1. 緒言}

世界の不織布生産の用途において，特に不織布製おむつ， 生理用品をはじめとした衛生材料用途の生産数量は圧倒的 に大きく，またその成長率も大きい1．特に不織布製掞む つの市場においては, 中国をはじめとしたアジア地域や, 中南米, 東欧市場の成長が著しく, 乳幼児用不織布招むつ のみならず，大人用㧍むつの開発も年々進んでいる，おむ つ用途に扔ける不織布の素材としては, ポリプロピレン (PP) スパンボンド不織布が主流となっており ${ }^{2)}$, 軽量で 適度の強度を有し, 耐医薬品性, リサイクル性にも優れ, コスト的にも競争力があることが特徴である ${ }^{3)}$.

おむつ用途における PP 不織布は, 直接身体に接触させ て使用されるため, 身体への良好な装着感や装着後の体の 動き易さなどの観点から, 柔軟性や風合い改良, 製品軽量 化のための薄目付化, 生産安定性向上のための紡糸性改良 に関連した技術開発が求められている. PP スパンボンド 不織布の柔軟性や風合い, 紡糸性を改良する手法として, 纎維の細繊度化に関する種々の検討が行われており, 特に 紡糸性の安定化と紡糸速度の高速化が期待されている.

これまでに我々は, PP 繊維の高速溶融紡糸において, 低立体規則性 PP を添加することで紡糸線上での結晶化と これに伴う急激な繊維の細化（ネック状変形）が抑制され， 高速での安定紡糸と繊維の細瀻度化が可能となることを示 してきだ, . 本報では，この技術を応用し，高立体規則 性 PP と低立体規則性 PP から成る相溶性ブレンドを用い, 纎維直径が細く, 均一性, 強度, 柔軟性のバランスに優れ る不織布の開発について報告する。

${ }^{* 1}$ Kohri, Youhei/Takebe, Tomoaki 出光興産(株) 機能材料研究所 市原市姉崎海岸 1-1（％299-0193） yohei.koori@idemitsu.com

*2 Kikutani, Takeshi/Takarada, Wataru 東京工業大学大学院理工学研究科有機・高分子物質専攻 東京都目黑区大岡山 2-12-1（殃152-8552）

${ }^{* 3}$ Kanai, Toshitaka

KT Polymer

袖ケ浦市蔵波 2411-3（テ299-0245）

2015. 4.6 受理

\section{2. 実験}

\section{1 試料}

本検討には，高立体規則性 PP（IPP：PP Exxon 3155, ExxonMobil 社製, $\left.\mathrm{MFR}=36 \mathrm{~g} / 10 \mathrm{~min}, \mathrm{Tm}=160^{\circ} \mathrm{C}\right)$ と, 低立体規則性 PP (LMPP : 出光興産侏製, 瀻維 - 不織布 用， MFR $\left.=50 \mathrm{~g} / 10 \mathrm{~min}, \mathrm{Tm}=75^{\circ} \mathrm{C}\right)$ を用いた。 LMPP は 二架橋メ夕ロセン触媒を用いて重合したものであり, IPP の融点が $160^{\circ} \mathrm{C}$ であるのに対し, LMPP は $75^{\circ} \mathrm{C}$ と低い值 を示すことからも, IPP に比べ著しく立体規則性が低い PP であることが分かる.

スパンボンド不織布成形には，このIPP を基準試料と し，IPPのみからなる IPP-100，IPP に LMPPを $10 \mathrm{wt} \%$ 添加したブレンド物 LMPP-10を用いた。

\section{2 スパンボンド不織布成形と紡系安定性評価}

不織布の成形には，ライコフィル社のスパンボンド第 4 世代機 REICOFIL 4 を用いた。スパンボンド不織布製造 装置は, 押出機, ダイ(ノズル径 $0.6 \mathrm{~mm}$ ，ノズル孔数 5800 hole $/ \mathrm{m}$ ), 加圧冷却システム (キャビンシステム), 延伸 チャンバ，サクションブロアー, コンベアベルト, カレン ダーロールおよび巻取り機から構成されている.

ここで，キャビンシステムとは紡糸線で繊維を延伸する 役割を果たすものである.ダイ直下のキャビン加圧エアー は空気抵抗力を生み出す加圧された冷却エアーであり, キャビン内に加圧空気を導入し, 絞り板の狭いクリアラン スにて高速の気流を生み出す。この気流と溶融纎維の速度 差より生じる空気抵抗力により, 瀻維が細化する.

本検討では，準備した試料を，押出機を用いてノズル径 $0.6 \mathrm{~mm}$ のノズルより樹脂温度 $245^{\circ} \mathrm{C}$, 単孔吐出量 $0.3 \sim$ $0.6 \mathrm{~g} / \mathrm{min} /$ hole で溶融押出し, キャビン圧力 $4000 \sim 6500$ $\mathrm{Pa}$ で紡糸することにより得られた瀻維をネット面に積層 し, 加熱したカレンダーロールでエンボス加工した後, 巻 取りロールに巻取り, 目付 $15 \mathrm{~g} / \mathrm{m}^{2}$ 不織布を得た。

紡糸安定性の評価は，3 分間ノズル直下での繊維破断の 有無を観察し, 繊維破断が発生しなかった場合を紡糸性が 安定しているとした。

\section{3 繊維直径計測}

非蒸着型走查型電子顕微鏡（SEM）を用いて，ランダ 
ムに選んだ 20 本の繊維について測定を行い，その平均值 を繊維直径とした．不織布分野では繊維の太さの指標（繊 度）として, 通常「デニール (denier)」という単位が用 いられることから，測定した繊維直径 $(\mu \mathrm{m})$ をデニール 值に換算した．更に，測定した繊維直径から各条件におけ る紡糸速度を算出した。

\section{4 超高速示差走査熱量計（FLASH DSC）測定}

成形に使用する樹脂の結晶化速度を評価するため, FLASH DSC（METTLER TOLEDO侏製）を用いた等温

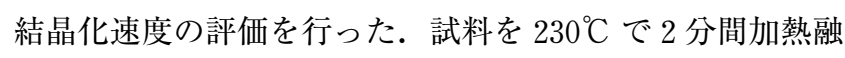
解させた後, $2000^{\circ} \mathrm{C} / \mathrm{s}$ で $25^{\circ} \mathrm{C}$ まで急冷し, $25^{\circ} \mathrm{C}$ での等温 結晶化過程における発熱量の時間変化を測定した. Flash DSC は非常に速い昇降温速度条件下において高精度の測 定が可能な熱分析機器であり, 従来測定不可能であった溶 融成形における急速冷却時の高次構造形成の観察を可能と するものである.

\section{5 均一性評価}

A 4 サイズに切り出した不織布に黒画用紙を重ね, ス キャナーを用い，画像をデジタルデータとしてパソコンに 取り込んだ。この際，全ての画像のピクセル数が同じにな るよう設定した. 次に, 取り込み画像データをグレースケー ル化してヒストグラムを作成した。ヒストグラムの作成に おいて, 白と黒の間の中間色を 256 階調の灰色で表現して おり，0が黒，255 が白であることを示す．ヒストグラム のピークを示すグレースケール值が大きい程, またヒスト グラムの分布が狭い程, 均一性の高い不織布であることを 示す.

\section{6 引張試験}

得られた不織布から, 長さ $200 \mathrm{~mm} \times$ 幅 $25 \mathrm{~mm}$ の試験 片を作製した.引張試験機（SHIMADZU Corporation, Autograph AG-I）を用い, 不織布の張力ーひずみ曲線の 測定を行った. チャック間距離は $100 \mathrm{~mm}$, 引張速度は 300 $\mathrm{mm} / \mathrm{min}$ とした. 少なくとも 5 本の試料の測定結果を平 均して $5 \%$ ひずみ強度, 破断強度, 破断ひずみを得た. 測定は，機械方向（MD）とこれに対し垂直な方向（TD） についてそれぞれ行った。

\section{3 ．結果と考察}

\subsection{PP スパンボンド不織布の紡糸性における低立体 規則性成分の添加効果}

表 1 に IPP-100，LMPP-10 の安定的に紡糸可能な単孔 吐出量, キャビン圧力の代表的な限界条件と, その繊度, 紡糸速度を示した. IPP-100の安定紡糸可能な標準条件は, 単孔吐出量 $0.6 \mathrm{~g} / \mathrm{min} /$ hole, キャビン圧力 $4500 \mathrm{~Pa}$ であり, 得られた不織布の繊度は $16.1 \mu \mathrm{m}$ (1. 7 denier) であった.
これに対し，低立体規則性成分を添加することで，低吐出 量条件や高キャビン圧力条件でも紡糸線での繊維破断が見 られず, 安定紡糸が可能な成形条件領域が広がり, $13.0 \mu \mathrm{m}$ (1. 0 denier) 程度までの細繊度化が可能となることが分 かった. 更に, IPP-100 の紡糸速度が約 $3200 \mathrm{~m} / \mathrm{min}$ であっ たのに対し, LMPP-10では最大で約 $4200 \mathrm{~m} / \mathrm{min}$ と, 高 速での安定紡糸が可能となることが分かった.

ここで，紡糸性向上の原因を考察するにあたり，REICOFIL 4 のようなダイからコンベアまでが閉鎖系のスパ ンボンド不織布成形機では, 紡糸線における繊維構造形成 を測定することが出来ない。このため，既報)で検討した 高立体規則性 PP (PP-STD), 高立体規則性 PP に低立体 規則性 PPを $10 \mathrm{wt} \%$ 添加した PP-LMC-10 の溶融紡糸実 験で得た細化挙動を元に，PP スパンボンド不織布の紡糸 性に対する低立体規則性 PP の添加効果を考察する。表 1 から, 今回のスパンボンド不織布成形において, LMPP を添加した場合の安定紡糸可能な最大紡糸速度が 3900〜 $4200 \mathrm{~m} / \mathrm{min}$ であったことから，考察する巻取速度は同程 度の $4000 \mathrm{~m} / \mathrm{min}$ とした。

巻取速度 $4000 \mathrm{~m} / \mathrm{min} に お け る \mathrm{PP}-\mathrm{STD}, \mathrm{PP}-\mathrm{LMC}-10$ の細化曲線を図 1 にそれぞれ示した。既報 でも考察した ように，低立体規則性 PP を添加することにより，細化の 完了点が下流にシフトするとともに, 細化曲線の形状が緩 やかになり，ネック状変形は抑制されていることが分かる. ここで, 紡糸線の変形挙動を定量化するため, 細化曲線を 解析し, 吐出口からの各位置における繊維のひずみ速度を, 式(1)，(2)を用いて算出した.

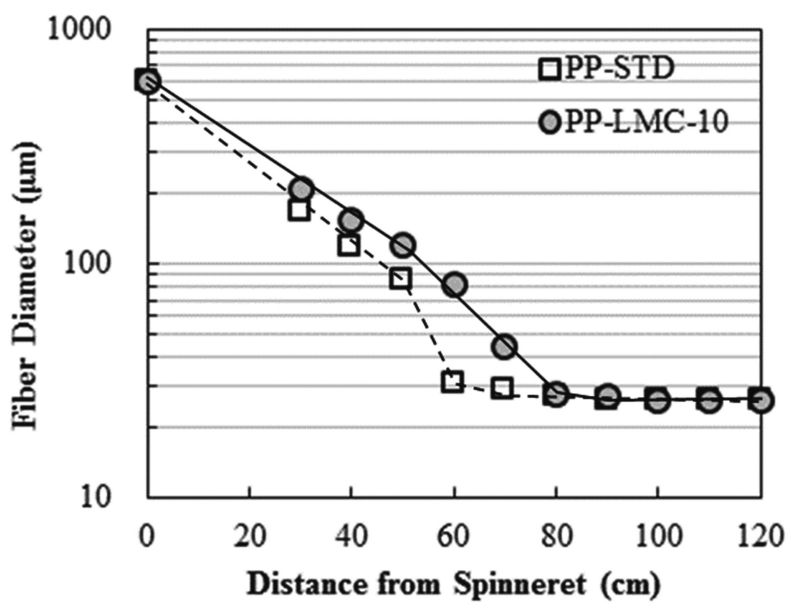

Fig. 1 Diameter profiles of spin-line at the take-up velocity of $4,000 \mathrm{~m} / \mathrm{min}$ for standard PP and PP blend containing low-molecular-weight and low tacticity component

Table 1 Fiber diameter and spinning velocity of various PP blends under the limit condition of stable spinning

\begin{tabular}{ccccccc}
\hline \hline $\begin{array}{c}\text { Sample } \\
\text { Code }\end{array}$ & $\begin{array}{c}\text { LMPP } \\
\text { Content } \\
(\mathrm{wt} \%)\end{array}$ & $\begin{array}{c}\text { Throughput } \\
(\mathrm{g} / \mathrm{min} / \text { hole })\end{array}$ & $\begin{array}{c}\text { Cabin } \\
\text { Pressure } \\
(\mathrm{Pa})\end{array}$ & $\begin{array}{c}\text { Fiber } \\
\text { Diameter } \\
(\mu \mathrm{m})\end{array}$ & $\begin{array}{c}\text { Fiber } \\
\text { Fineness } \\
(\text { denier })\end{array}$ & $\begin{array}{c}\text { Spinning } \\
\text { Velocity } \\
(\mathrm{m} / \mathrm{min})\end{array}$ \\
\hline IPP-100 & 0 & 0.6 & 4,500 & 16.1 & 1.7 & 3,200 \\
LMPP-10-1 & 10 & 0.6 & 6,500 & 14.7 & 1.4 & 3,900 \\
LMPP-10-2 & 10 & 0.5 & 6,500 & 13.2 & 1.1 & 4,200 \\
LMPP-10-3 & 10 & 0.4 & 5,500 & 13.4 & 1.1 & 3,300 \\
\hline
\end{tabular}




$$
\begin{gathered}
v_{x}=\frac{4 M}{\left(\rho \pi d_{x}^{2}\right)} \\
\dot{\varepsilon}=\frac{\left(d v_{x}\right)}{d x}
\end{gathered}
$$

ここで, 単孔吐出量を $M$, 密度を $\rho$, 各位置における 繊維直径を $d_{x}$, 紡系速度 $v_{x}$, ひずみ速度を $\dot{\varepsilon}$ とした. 図 2 に吐出口からの位置に対するひずみ速度変化をそれぞれ示 した. PP-STD に対し PP-LMC-10の最大ひずみ速度が $20 \%$ 程度低下したことが分かる．このことから，低立体 規則性 PP の添加により紡糸線での急激な変形が抑制され たことが示唆される. また，PP-STD に対し PP-LMC-10 の最大ひずみ速度のピーク位置が下流へシフトしことから， 低立体規則性 PP の添加により紡糸線での結晶化が抑制さ れ, 変形位置が下流へシフトしたことが示唆される.ここ で示したひずみ速度の值は，紡糸線上の直径変化を $10 \mathrm{~cm}$ 間隔で測定した結果に基づいたものであり，その絶対值は， 測定間隔を変更することで変化することから, 定性的な議 論に留める.

ここで，低立体規則性 PP の添加により PP の結晶化が 抑制されると述べたが, 高立体規則性 PP は室温環境下で の結晶化速度が著しく速いため, 汎用性の高いポリマーで あるにもかかわらず，その正確な結晶化速度の測定はこれ まで出来ておらず，低立体規則性 PP を添加することによ りどの程度結晶化が抑制されるのかを定量化出来ていな かった ${ }^{6)}$.

そこで，低立体規則性 PP 添加による PP の結晶化抑制 効果について, FLASH DSCを用いた測定を行った。試 料には IPP-100\%（Y 2005 GP：株)プライムポリマー社製， $\left.\mathrm{Tm}=161^{\circ} \mathrm{C}, \mathrm{Mw}=2.0 \times 105, \mathrm{Mw} / \mathrm{Mn}=4.8\right)$ と $\mathrm{LMPP}-$ 10\%（Y $2005 \mathrm{GP} / \mathrm{LMPP}=90 \mathrm{wt} \% / 10 \mathrm{wt} \% ）$ を用いた。

図 3 に等温結晶化開始時から結晶化完了時までの発熱量の 積分值を $100 \%$ とした時の, 結晶化時間に対する相対結晶 化度曲線を示した. 相対結晶化度が $50 \%$ に到達する半量 結晶化時間で比較すると, IPP-100\% が 0.066 秒であった

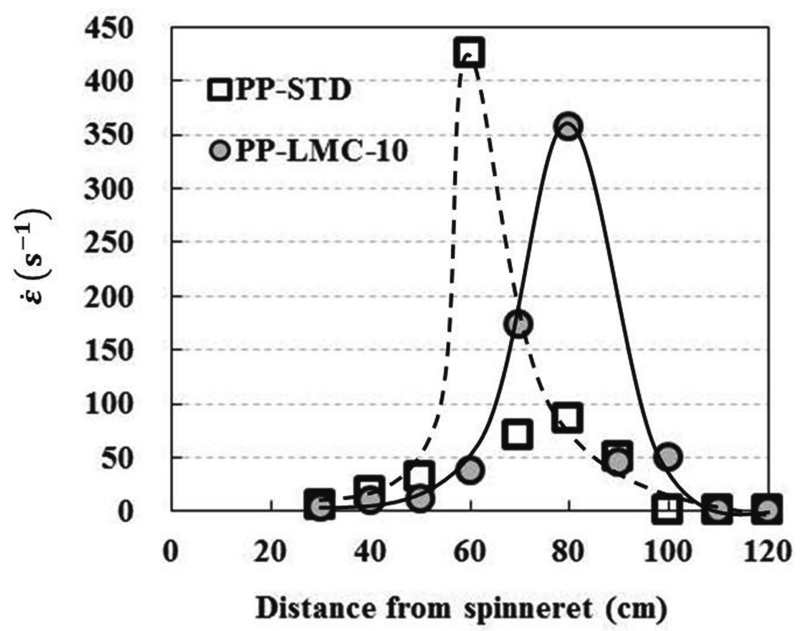

Fig. 2 Strain rate profiles of spin-line at the take-up velocity of $4,000 \mathrm{~m} / \mathrm{min}$ for standard $P P$ and PP blend containing low-molecular-weight and low tacticity component

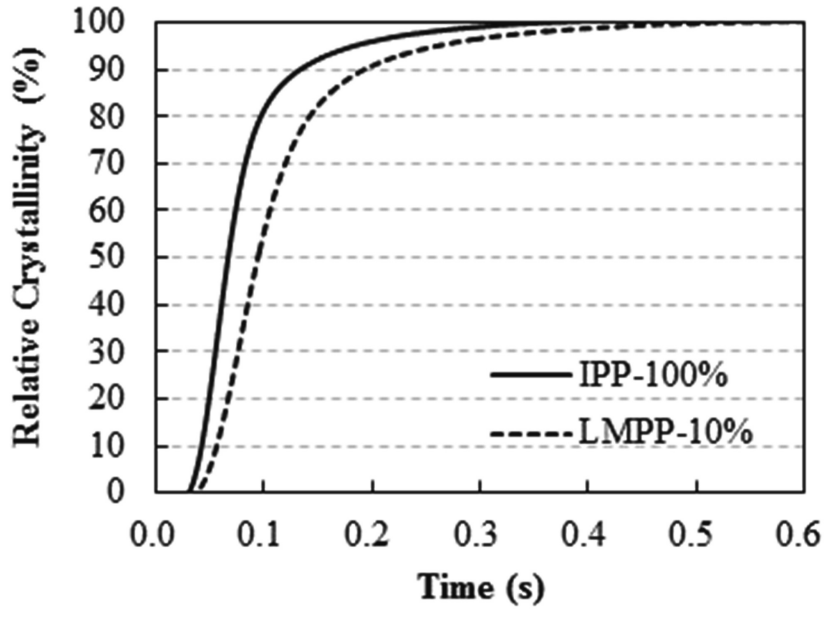

Fig. 3 Time variation of relative crystallinity for standard PP and PP blend containing low tacticity component

のに対し, LMPP-10\%は 0.094 秒と半量結晶化時間が 1.5 倍程度遅くなっていることが確認された。

スパンボンド不織布成形において, 紡糸速度 $4000 \mathrm{~m} /$ min 程度の PP 繊維の結晶化がダイからコレクターまでの $3.5 \mathrm{~m}$ の間で完了すると考えた場合, その時間は 0.2 秒以 下となる，厳密に述べると, 紡糸線上での結晶化可能な温 度域は, 細化完了点から室温に到達するまでの区間程度で あり，この区間に繊維が滞在する時間で結晶化が完了する ためには, 配向誘起の構造形成が不可欠である. Flash DSC を用いた結晶化速度の測定結果は, 配向結晶化などの高次 構造形成の因子を含まない結果であることを鑑みれば，半 量結晶化時間のオーダーから見ても妥当性があるといえる。 このことからも，低立体規則性 PP の添加による紡糸性 の向上には，紡糸線上での結晶化抑制とそれに伴う急激な 変形の抑制効果が起因していると考えられる.

\section{2 細繊度化が PP スパンボンド不織布の性能へ及ほ す効果}

図 4 に不織布の均一性評価により得た, IPP-100, LMPP -10-1, LMPP-10-2, LMPP-10-3 のグレースケールのヒ

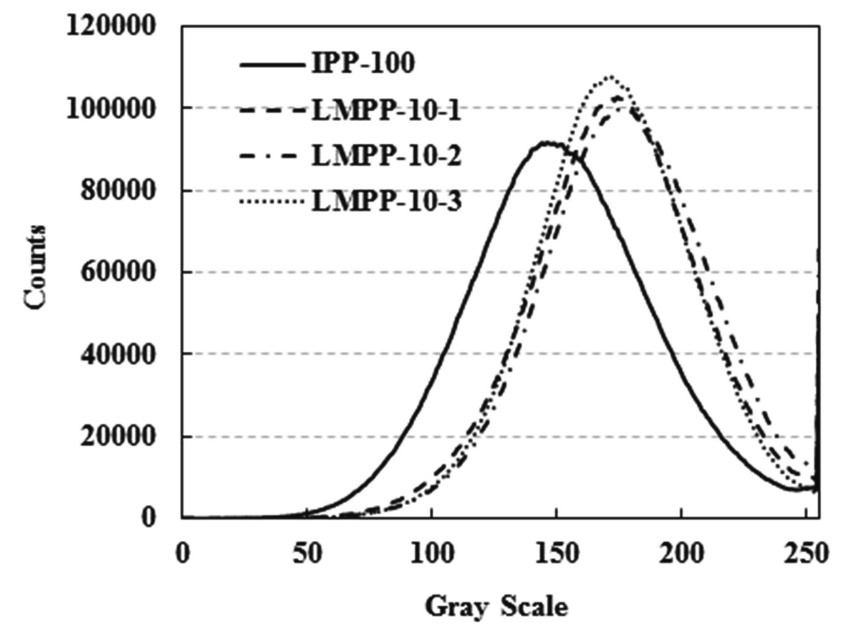

Fig.4 Gray scale histogram of the image of spunbond nonwoven fabrics for standard PP and PP blend containing low tacticity component with different fiber fineness 
Table 2 Load at 5\% strain, strain at break and tensile strength of various PP blends nonwoven fabrics produced under the limit condition of stable spinning

\begin{tabular}{|c|c|c|c|c|c|c|c|c|c|c|}
\hline \multirow[t]{2}{*}{$\begin{array}{l}\text { Sample } \\
\text { Code }\end{array}$} & \multirow[t]{2}{*}{$\begin{array}{l}\text { Throughput } \\
\text { (g/min/hole) }\end{array}$} & \multirow{2}{*}{$\begin{array}{l}\text { Cabin } \\
\text { Pressure } \\
\quad(\mathrm{Pa})\end{array}$} & \multirow{2}{*}{$\begin{array}{c}\text { Fiber } \\
\text { Diameter } \\
(\mu \mathrm{m})\end{array}$} & \multirow{2}{*}{$\begin{array}{c}\text { Fiber } \\
\text { Fineness } \\
\text { (denier) }\end{array}$} & \multicolumn{2}{|c|}{$\begin{array}{c}\text { Load at } 5 \% \\
\text { Strain } \\
(\mathrm{N} / 5 \mathrm{~cm})\end{array}$} & \multicolumn{2}{|c|}{$\begin{array}{c}\text { Strain at } \\
\text { Break }(\%)\end{array}$} & \multicolumn{2}{|c|}{$\begin{array}{l}\text { Tensile } \\
\text { Strength } \\
(\mathrm{N} / 5 \mathrm{~cm})\end{array}$} \\
\hline & & & & & $\mathrm{MD}$ & $\mathrm{TD}$ & $\mathrm{MD}$ & TD & $\mathrm{MD}$ & $\mathrm{TD}$ \\
\hline IPP-100 & 0.6 & 4,500 & 16.1 & 1.7 & 9.3 & 2.3 & 43 & 50 & 32 & 15 \\
\hline LMPP-10-1 & 0.6 & 6,500 & 14.7 & 1.4 & 6.2 & 1.2 & 60 & 69 & 32 & 17 \\
\hline LMPP-10-2 & 0.5 & 6,500 & 13.2 & 1.1 & 8.7 & 1.5 & 72 & 79 & 45 & 20 \\
\hline LMPP-10-3 & 0.4 & 5,500 & 13.4 & 1.1 & 8.8 & 1.4 & 67 & 87 & 45 & 21 \\
\hline
\end{tabular}

ストグラムを示した. IPP-100 に対し, LMPP-10-1, LMPP -10-2，LMPP-10-3 はヒストグラムのピークが高いグレー スケール值を示し，その分布も狭いことが確認できる。こ のことから，低立体規則性 PP 添加による細繊度化を可能 としたことで, 瀻維の分散性が向上し, 不織布の均一性が 向上したことが分かる.

次に, 図 5 に引張試験により得た IPP-100, LMPP-101, LMPP-10-2, LMPP-10-3 の不織布の, MD 方向, TD 方向における張力ーひずみ曲線をそれぞれ示した．更に， 表 2 に図 5 を解析して得た MD 方向，TD 方向それぞれの $5 \%$ ひずみにおける張力, 強度, 破断ひずみを示した. ここで，5\%ひずみにおける強度とは，不織布をひずみ $5 \%$ まで伸長した時に示す張力のことであり, 初期弾性 率と同じく不織布の剛性を示す指標となる.

IPP-100 と LMPP-10-1 の比較から, 単孔吐出量を一定 とした場合, LMPPを添加し $14.7 \mu \mathrm{m}$ (1.4 denier) まで 細瀻度化することにより, 破断強度が向上することが分 かった. 更に単孔吐出量を少量化し, $13.2 \mu \mathrm{m}$ (1. 1 denier) まで細緘度化することにより, MD, TD 方向共に破断強度, 破断ひずみが大幅に向上していることが分かった．一方， 初期弾性率を示す $5 \%$ ひずみ強度は, 纎維を細瀻度化し たにもかかわらず IPP-100 に比べ低い值を示し，不織布 の柔軟性が向上したことが分かる。これは，低立体規則性 PPの添加により瀻維の結晶化度が低下したことに起因す ると考えられる.

細瀻度化による不織布強度の向上には，エンボスで熱融 着される繊維の本数が起因していると推察される. 標準条 件で成形した IPP-100 と， LMPPを $10 \mathrm{wt} \%$ 添加し細瀻度 化条件で成形した LMPP-10-2 について，スパンボンド不 織布のエンボス点を拡大したSEM 画像を図 6 に示した。 この図から，LMPP を添加し細瀻度化することで, エン ボス点で熱融着される瀻維の本数が増えていることが確認 できる．細繊度化により，エンボスで熱融着される瀻維の 本数が増えることで, 不織布中の繊維の拘束力が強くなり 不織布の強度が向上したと考えられる。

\section{4. 結言}

本報では, PP スパンボンド不織布の製造における，細 繊度化条件での紡糸安定性向上と不織布の均一性, 力学物 性, 柔軟性のバランス改良を試みた。不織布を構成する IPP 瀻維に低立体規則性 PP（LMPP）をブレンドすることで, 紡糸安定性, 高速紡糸性に優れ, 均一性, 強度, 柔軟性の
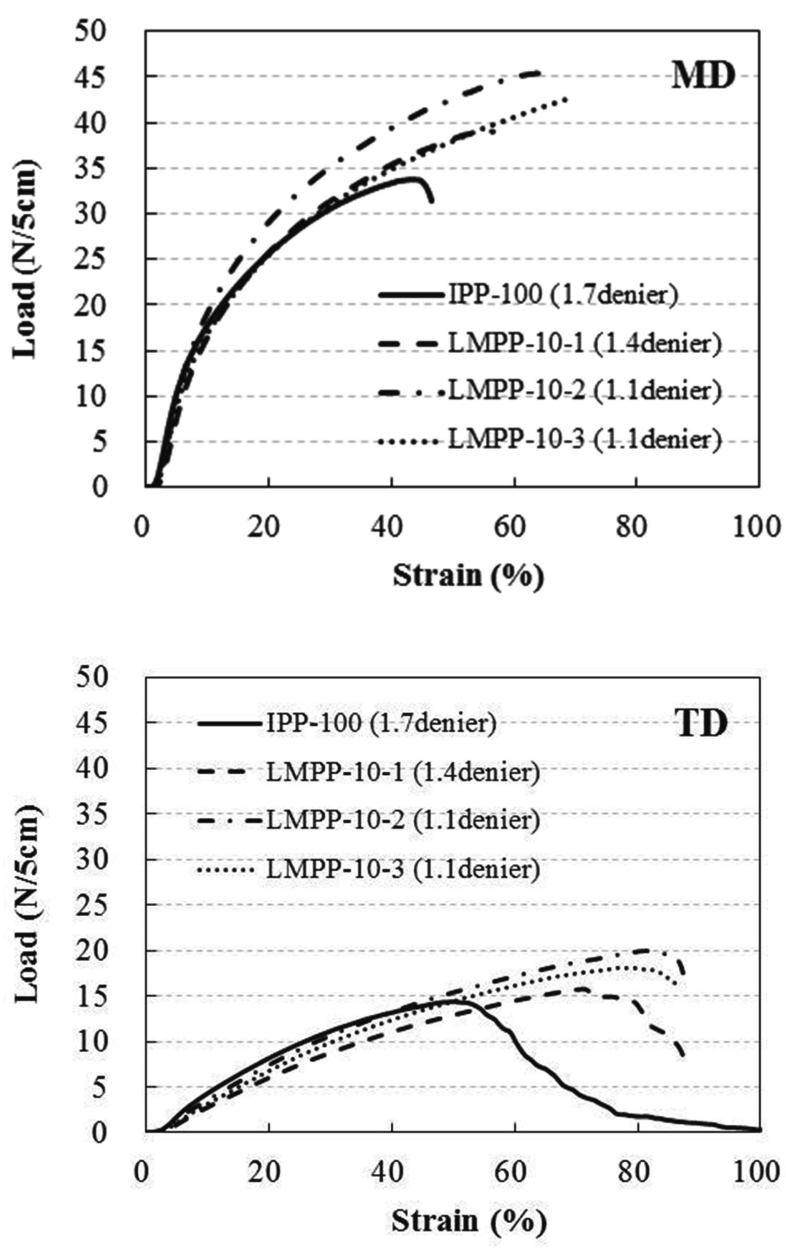

Fig. 5 Load-Strain curves in MD and TD of spunbond nonwoven fabrics for standard $P P$ and $P P$ blend containing low tacticity component with different fiber fineness

バランスに優れた不織布の工業的な生産が可能となった.

特に紡糸性の安定化と細繊度化には, 低立体規則性 PP を添加することによる, 紡系線での結晶化抑制効果と, こ れに伴う纎維の急激な変形（ネック状変形）の抑制効果が 起因していると考察した. 


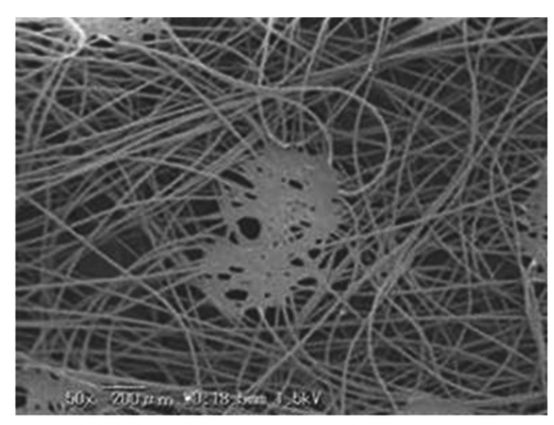

IPP-100, $16.1 \mu \mathrm{m}$ (1.7denier)

Throughput: $0.6 \mathrm{~g} / \mathrm{min} / \mathrm{hole}$

Cabin Pressure : 4,500Pa

MD Strength : $32 \mathrm{~N} / 5 \mathrm{~cm}$

TD Strength : $15 \mathrm{~N} / 5 \mathrm{~cm}$

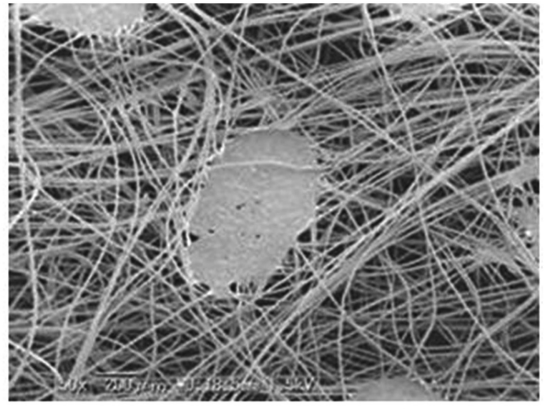

LMPP-10-2, 13.2 $\mu \mathrm{m}$ (1.1denier)

Throughput: $0.5 \mathrm{~g} / \mathrm{min} / \mathrm{hole}$

Cabin Pressure : 6,500Pa

MD Strength : $45 \mathrm{~N} / 5 \mathrm{~cm}$

TD Strength : $20 \mathrm{~N} / 5 \mathrm{~cm}$

Fig. 6 Enlarged view of embossing pattern for standard PP and PP blend containing low tacticity component with different fiber fineness observed with SEM

\section{参 考 文 献}

1) (株東レリサーチセンター：不織布の最新技術と用途展 開，(侏黎明社，6(2011)

2 ) (侏東レリサーチセンター: 不織布の最新技術と用途展 開，(株黎明社，330(2011)

3 ) (株東レリサーチセンター: 不織布の最新技術と用途展 開，株黎明社，36(2011)
4 ) 郡洋平, 宝田亘, 伊藤浩志, 武部智明, 南裕, 金井俊 孝, 鞠谷雄士：成形加工' 08,20 (11)，831(2008)

5 ) Okumura, A., Ito, H., Kikutani, T., Kanai, T. : Polymer Processing Society Annual Meeting in Leipzig, PPS-21 (2005)

6 ） METTLER TOLEDO 社：技術資料「超高速 DSC 測 定装置」 